\title{
ANALISIS PEMAHAMAN MAHASISWA TADRIS IPA TENTANG KONSEP PERKEMBANGAN JANIN DALAM PERSPEKTIF ISLAM DAN SAINS
}

\author{
Elsa Novella1, Rian Vebrianto ${ }^{2}$, Zarkasih ${ }^{3}$ \\ 1,2,3Program Magister Pendidikan Guru Madrasah Ibtidaiyah, UIN Sultan Syarif Kasim Riau \\ 1,2,3 Jalan H.R. Soebrantas No. 155 Km 15 Simpang Baru Panam Pekanbaru \\ Email: elsanovellatanjung@gmail.com ${ }^{1}$, rhayent23ukm@gmail.com² ${ }^{2}$, zarkasih@gmail.com³
}

\begin{abstract}
Abstrak:
Penelitian ini bertujuan untuk mengetahui pemahaman mahasiswa tadris IPA mengenai konsep perkembangan janin dalam perspektif Islam dan sains. Jenis penelitian menggunakan design survey. Penelitian dilakukan di prodi tadris IPA dengan mengambil sampel secara acak sehingga didapat 30 orang mahasiswa yang telah mempelajari konsep IPA dalam perspektif Islam dan sains. Instrumen pengumpulan data penelitian menggunakan angket yang sudah divalidasi terdiri dari 15 pernyataan. Hasil analisis menunjukkan bahwa pemahaman mahasiswa tadris IPA tentang konsep perkembangan janin dalam perspektif Islam dan sains termasuk kategori tinggi.
\end{abstract}

\begin{abstract}
:
This study aims to determine the understanding of Tadris IPA students about the concept of fetal development in Islamic and scientific perspectives. This type of research uses survey design. The study was conducted at the Natural Sciences Tadris Study Program by taking a random sample so that 30 students were obtained who had studied the science concept in Islamic and scientific perspectives. The research data collection instrument used a validated questionnaire consisting of 15 statements. The results of the analysis showed that Tadris IPA's students' understanding of the concept of fetal development in Islamic and scientific perspectives was high.
\end{abstract}

\section{Kata kunci: \\ Perkembangan Janin, Perspektif Islam, Sains}

How to Cite: Novella, E., Vebrianto, R., \& Zarkasih. (2019). Analisis Pemahaman Mahasiswa Tadris IPA tentang Konsep Perkembangan Janin dalam Perspektif Islam dan Sains. Lentera Pendidikan : Jurnal Ilmu Tarbiyah dan Keguruan, 22(2), 292-301.

\section{PENDAHULUAN}

Al-Qur'an memiliki banyak ayat-ayat yang menyentuh tentang ilmu pengetahuan dan ilmuan. Al-Qur'an senantiasa mengarahkan manusia untuk menggunakan akal pikirannya dan memberi motivasi meningkatkan ilmu pengetahuan. Al-Qur'an juga memberikan penghargaan yang tinggi terhadap ilmuan untuk berusaha dan bekerja serta selalu berdo'a agar ditambah ilmu pengetahuan. Sementara itu Rasulullah memberi pengakuan bahwa ilmuan itu merupakan pewaris para Nabi. Al-Quran ataupun sains menggambarkan proses perkembangan janin manusia sebagai mahluk yang sempurna dan terus mengalami perubahan fisik serta mental, mulai usia konsepsi, infansi, bayi, kanak-kanak, remaja, dewasa sampai 
meninggal. Usia dalam kandungan adalah fase penentuan dan penetapan seluruh nasib manusia di dunia dan akhirat. Perspektif Islam menjelaskan dalam surah AlMu'minun ayat 12-14. Menurut Zakiah Daradjat dalam Ma'ruf (2017: 125) menyatakan pembentukan identitas anak menurut Islam, dimulai jauh sebelum anak diciptakan. Islam memberikan berbagai syarat dan ketentuan pembentukan keluarga, sebagai wadah yang akan mendidik anak sampai umur tertentu yang disebut baligh berakal. Proses penciptaan manusia diawali dari saripati makanan yang dikonsumsi yang bersumber dari tanah kemudian dijadikan nutfah yang bercampur antara sel kelamin jantan (spermatozoa) dan sel kelamin betina (ovum) yang dikenal sebagai nutfah, dalam ilmu kedokteran disebut konsepsi yang terletak di dalam tempat kokoh yakni rahim yang memiliki struktur yang mampu melindungi janin (Latjnah, 2010).

Nutfah yang bercampur tersebut dijadikan segumpal darah yang menempel pada dinding rahim. Peristiwa ini dalam ilmu kedokteran disebut proses implantasi. Di antara fase-fase yang pasti akan dialami oleh setiap manusia, disebut fase nutfah yang merupakan air (sperma laki-laki) yang memancar ke dalam rahim perempuan. Sebagaimana Allah telah menjelaskan dalam firman-nya surah At-Tariq ayat 5-6: "Maka hendaklah manusia memperhatikan dari apakah dia diciptakan? Dia diciptakan dari air yang dipancarkan." Pancaran tersebut hanya berasal dari laki-laki. Jadi, yang dimaksud dengan nutfah adalah proses antara sperma laki-laki dan sel telur perempuan yang telah bersatu. Dalam perkembangannya, sebelum menjadi bayi yang dilahirkan, seseorang melalui berbagai fase tahapan di dalam kandungan sang ibu (Suwito, 2012: 198). Menurut Al-Qurtubi (2003), terdapat 3 fase dalam kandungan. Fase pertama, yaitu nutfah yang merupakan pertemuan sperma laki-laki dan indung telur perempuan yang melebur di dalam rahim perempuan, dan pada proses itulah janin terbentuk. Fase kedua, disebut 'alaqah, yaitu ketika sperma jatuh ke dalam rahim selama 6-7 hari akan terbentuk buih. Pada hari tersebut nutfah sudah terbentuk dan tidak melekat dalam dinding rahim. Setelah 6 hari tepatnya hari ke-15 dari waktu pembuahan tersebut darah mulai mengaliri keseluruhnya sehingga membentuk 'alaqah atau embrio yang melekat dalam rahim (Abu al-Farj, 2003).

Akibat percampuran antara sperma laki-laki dan indung telur perempuan sehingga terbentuklah gumpalan darah yang membeku. Hal ini terdapat dalam surah Al-Mu' minun ayat 14, yaitu "Kemudian air mani itu Kami jadikan segumpal darah...." Kemudian fase ketiga, janin yang seukuran sepotong daging yang disebut mudhghah, beberapa ulama mengatakan di fase mudhghah terbagi dua jenis, yaitu penciptaan yang sudah sempurna dan penciptaan yang belum sempurna (Al-Razi, 2000). Dalam tiga tahapan fase kehamilan membutuhkan waktu 40 hari sebelum beralih ke fase berikutnya. Ketika janin telah memasuki waktu 120 hari, maka akan terjadi peniupan ruh dan terjadinya penciptaan baru, hal ini sesuai dengan beberapa mayoritas ahli tafsir. Para ahli tafsir ini berpegang teguh karena berdasarkan hadits Nabi Saw. "Sesungguhnya selama 40 hari seorang manusia mulai diciptakan dalam rahim ibunya. Lalu membentuk segumpal daging di 40 hari berikutnya, 40 hari kemudian Allah menuliskan rezeki, ajal, amal, dan kebahagian/ kesengsaraan." 
Perspektif sains kehamilan terjadi pada saat wanita berada pada masa ovulasi atau keadaan subur (rahim melepaskan sel telur), dan sperma (air mani) pria mulai membuahi sel telur dari wanita atau proses pembuahan (konsepsi), hal tersebut mengawali proses-proses dalam kehamilan (Surana, 2001). Kurun waktu 40 minggu atau 280 hari sel telur yang telah dibuahi akan tumbuh dan berkembang serta terjadi perubahan di permukaan sel telur (fertilisasi) untuk mencegah penetrasi oleh sperma lain yang mendekati sel telur. Sel telur yang telah dibuahi mulai membelah dan tumbuh di dalam tuba fallopi secara cepat membentuk menjadi morulla (Hanifah, 2005).

Setelah menempel pada endometrium beberapa sel berkembang menjadi plasenta. Dalam 3 minggu berikutnya pada pasca ovulasi sekitar 3 minggu terjadi pembentukan otak, sumsum tulang belakang, serta terbentuknya jantung. Di minggu ke-5 detak jantung janin dan tali pusar mulai terlihat ketika menuju minggu ke-7. Pada minggu ke-8 janin telah berukuran 2,5 cm (Yuliati, 2000).

Pada minggu ke-4 sampai ke-8 muka dan leher yang telah terbentuk, selain itu pangkal hidung sudah terlihat jari-jari sudah mulai berpisah, kelopak mata dan telinga juga sudah terlihat, perkembangan jantung dan pembuluh darah sehingga paru-paru, lambung dan hepar juga terbentuk. Janin terus berkembang yang terlihat dari gerakan janin yang dapat diraba menggunakan alat khusus untuk mendengarkan detik jantung janin. Sudah terlihat alat kelamin dan proeses segala pembententukan sudah mulai sempurna pada minggu ke-20 berikutnya.

Menurut Syauman (2004) telah terbukti secara ilmiah bahwa sejak embrio janin terus berkembang sehingga saat ini telah ada alat yang digunakan untuk mendengar detak jantung janin pada usia 5 minggu. Dalam ilmu kedokteran disebut sebagai USG yang merupakan alat untuk memeriksa kondisi janin yang ada dalam rahim. Pada kehamilan 28-36 Minggu perkembangan janin sudah sangat berkembang yaitu janin dapat merespon suara dan gerakan yang umumnya janin sudah berada di posisi untuk segera lahir sehingga harus segera berkonsultasi kepada dokter untuk mempersiapkan catatan perhitungan sebelum proses kelahiran berlangsung (Yuliati, 2000).

Perkembangan janin dalam pandangan Islam dan sains tidak ada pertentangan sehingga dikatakan bahwa sains telah membuktikan kebenaran dari Al-Qur'an mengenai perkembangan janin dalam rahim manusia. Selain itu, teknologi yang telah diciptakan manusia untuk membuktikan kebenaran dari surah Al-Mu'minun ayat 1214 senantiasa membuat kita semakin lebih mendekatkan diri kepada Allah Swt. Hathout \& Samer (2002) dalam sebuah pidato dengan tema "Keselarasan Ilmu Kandungan dengan Apa yang Terdapat dalam Al-Qur'an dan As-Sunnah" di Universitas Al-Malik Faishal, berkata, "Sungguh membuktikan kepada saya bahwa ilmu pengetahuan terdapat dalam Al-Qur'an, memberikan bukti bahwa Al-Qur'an dari sisi Allah yang telah dibawa oleh utusan Allah seorang rasul yaitu Muhammad Saw. Menurut Ichromi (2016: 9) fenomena yang berkembang di masyarakat adalah banyaknya ibu yang mengandung tetapi kurang memperhatikan pendidikan bagi janin yang dikandungnya, padahal dalam Al-Qur'an telah dijelaskan akan pentingnya 
memelihara janin dalam kandungan untu tumbuh kembang anak di hari kemudian. Jadi terdapat integrasi antara ilmu yang ada di dalam Al-Quran dengan ilmu dalam sains, keterpaduan itu dapat memberikan kontribusi bagi perjalanan dan pengembangan ilmu pengetahuan ke arah rahmatan li alamin dan taqarrub ila Allah sehingga ilmu secara ontologis menumbuhkembangkan dan memperkuat keimanan kepada Allah rabb al alamin dan terbentuknya insan kamil yang memaslahatkan umat.

Berdasarkan fakta-fakta tersebut mahasiswa tadris IPA/calon guru IPA harus dapat mengintegrasikan antara konsep ilmu Islam dengan sains sehingga keseimbangan antara ilmu sains dan Islam dapat membentuk insan kamil yang memaslahatkan umat, mahasiswa tadris IPA/calon guru IPA juga harus memiliki pemahaman konsep untuk dapat mengintegrasikan keduanya. Tuntutan dari perkembangan IPTEK dan era industri ini mengharuskan adanya kontribusi ilmu Islam dengan ilmu sains. Oleh karena itu, peneliti tertarik untuk mengkaji pemahaman mahasiswa tadris IPA/calon guru IPA mengenai konsep perkembangan janin dalam perspektif sains dan Islam. Untuk itu, perlu dilakukan analisis pemahaman mahasiswa tadris IPA.

\section{METODE PENELITIAN}

Jenis penelitian ini menggunakan design survey. Menurut Arikunto (2004), penelitian survey adalah penelian yang menggambarkan fenomena yang apa adanya tentang suatu variabel, gejala atau keadaan dan tidak dimaksudkan untuk menguji hipotesis tertentu. Penelitian deskriptif ini dilakukan dengan tujuan untuk mengetahui pemahaman konsep perkembangan janin dalam perspektif sains dan Islam. Populasi penelitiannya adalah seluruh mahasiswa tadris IPA UIN Sultan Syarif Kasim Riau, Pekanbaru. Sampel penelitian ini adalah 30 orang mahasiswa tadris IPA. Tahapan penelitian meliputi pembuatan angket, penyebaran dan pengisian oleh responden, dan analisis data. Teknik pengumpulan data dalam penelitian ini menggunakan angket skala likert, yaitu STS (Sangat Tidak Setuju), KS (Kurang Setuju), TT (Tidak Tahu), S (Setuju), SS (Sangat Setuju) dengan 15 item pertanyaan. Lembar angket disusun berdasarkan indikator konsep Islam dan sains tentang perkembangan janin manusia yang terdiri dari beberapa pernyataan positif dan pernyataan negatif. Teknik analisis data dalam penelitian ini menggunakan analisis deskriptif kuantitatif.

\section{HASIL PENELITIAN DAN PEMBAHASAN}

Pada penelitian ini, analisis mengenai pemahaman mahasiswa tadris IPA tentang konsep perkembangan janin dalam perspektif Islam dan sains menggunakan pernyataan yang tersaji dalam tabel 1 . Adapun data hasil penelitian sebagai berikut. 
Tabel 1. Hasil Analisis Pernyataan yang Positif (Sesuai dengan Sains dan Islam)

\begin{tabular}{|c|c|c|c|}
\hline No & Pernyataan & Mean & Kategori \\
\hline 1 & $\begin{array}{l}\text { Pernyataan } 1 \text { (dalam Islam perkembangann janin } \\
\text { terjadi karena air mani) }\end{array}$ & 4,83 & Sangat Setuju \\
\hline 2 & Pernyataan 2 (air mani terbentuk dari saripati tanah) & 4,97 & Sangat Setuju \\
\hline 3 & $\begin{array}{l}\text { Pernyataan } 6 \quad \text { (terbentuknya janin terjadi ketika } \\
\text { pertemuan antara sel sperma dengan sel telur) }\end{array}$ & 4,93 & Sangat Setuju \\
\hline 4 & $\begin{array}{l}\text { Pernyataan } 7 \text { (pertemuan sel sperma dan sel telur } \\
\text { terjadi di tuba fallopi) }\end{array}$ & 4,67 & Sangat Setuju \\
\hline 5 & $\begin{array}{l}\text { Pernyataan } 8 \text { (morula meninggalkan tuba fallopi dan } \\
\text { masuk ke dalam uterus 3-4 hari pasca fertilisasi) }\end{array}$ & 4,63 & Sangat Setuju \\
\hline 6 & $\begin{array}{l}\text { Pernyataan } 9 \text { (pada minggu ke-4 terjadi perkembanagn } \\
\text { pembuluh jantung dan darah) }\end{array}$ & 4,20 & Sangat Setuju \\
\hline 7 & $\begin{array}{l}\text { Pernyataan } 10 \text { (pada minggu ke- } 8 \text { telah terjadi } \\
\text { pembentukan kelopak mata dan telinga) }\end{array}$ & 4,17 & Setuju \\
\hline 8 & $\begin{array}{l}\text { Pernyataan } 11 \text { (pada minggu ke- } 12 \text { dengan alat khusus } \\
\text { sudah dapat didengar detak jantung janin) }\end{array}$ & 4,37 & Sangat Setuju \\
\hline 9 & $\begin{array}{l}\text { Pernyataan } 12 \text { (pada minggu ke-16 mata sudah dapat } \\
\text { berkedip dan pembentukan jantung serta pembuluh } \\
\text { dara sudah sempurna) }\end{array}$ & 4,03 & Setuju \\
\hline 10 & $\begin{array}{l}\text { Pernyataan } 13 \text { (pemeriksaan USG umumnya dilakukan } \\
\text { pada kehamilan } 20 \text { minggu) }\end{array}$ & 4,77 & Sangat Setuju \\
\hline 11 & $\begin{array}{l}\text { Pernyataan } 14 \text { (peniupan ruh terjadi setelah } 120 \text { hari } \\
\text { dalam perspektif Islam) }\end{array}$ & 4,77 & Sangat Setuju \\
\hline 12 & $\begin{array}{l}\text { Pernyataan } 15 \text { (proses penciptaan manusia terdapat } \\
\text { dalam surah Al-Mu'minun ayat } 12-14\end{array}$ & 4,97 & Sangat Setuju \\
\hline
\end{tabular}

Konsep perkembangan janin dalam Islam dan sains termuat dalam pernyataan 1, yaitu dalam Islam perkembangan janin terjadi karena air mani, dari hasil angket yang dibagikan jawaban mahasiswa Tadris IPA adalah sangat setuju dengan nilai rata-rata 4,83. Secara statistik jumlah responden ada 30 orang, terdapat 25 orang mahasiswa yang menjawab sangat setuju, 5 orang mahasiswa yang menjawab setuju. Dari hasil tanggapan respon ini mahasiswa Tadris IPA sudah memahami konsep mengenai perkembangan janin dalam Islam yang terjadi karena air mani. Hal ini sesuai dengan surat Surah Al-Tariq ayat 5-6, bahwa "Dia menciptakan manusia dari air yang memancar, maka hendaklah manusia memperhatikan dari apakah dia diciptakan? Dia diciptakan dari air yang dipancarkan. Pancaran tersebut hanya berasal dari laki-laki." Dari ayat tersebut banyak para ulama dan tafsir yang mengatakan bahwa yang dimaksud nutfah itu adalah proses bertemunya sperma laki-laki dan sel telur perempuan. Selain itu, menurut Abu al-Husain Muslim (2003) tulang sulbi laki-laki dan tulang dada dalam pendapat beberapa ulama yang juga disebut oleh Hadis Nabi saw: "Seorang laki-laki memiliki mani berwarna putih, sedangkan wanita berwarna 
kuning, jika mani tersebut menyatu lalu mani putih tersebut lebih dominan maka atas izin Allah janin tersebut akan berkelamin laki-laki". Pada pernyataan 1, mahasiswa tadris IPA tidak ada yang mengalami miskonsepsi pada pernyataan yang menyatakan bahwa dalam Islam perkembangan janin terjadi karena air mani.

Selanjutnya, pernyataan 2 menerangkan bahwa air mani terbentuk dari saripatih tanah. Secara statistik terdapat 29 mahasiwa tadris IPA menyatakan sangat setuju, sedangkan yang menjawab setuju hanya 1 mahasiswa saja, dengan rata-rata 4,97 dengan kategori sangat setuju. Jika merujuk kepada teori dimana ketika saripati tanah masuk ke dalam tubuh manusia, maka saripati itu akan dipakai oleh tubuh sebagai starting metabolism dalam pembentukan nutfah di dalam sel-sel reproduksi. Secara literal kata nutfah ini berarti tetesan atau bagian kecil dari fluida atau cairan kental konsetrat. Nutfah amsyaj atau setetes mani yang bercampur merupakan hasil campuran antara nutfah/benih laki-laki (sperma) dengan sel telur wanita seperti dalam Surah Al Insan/6:2 tampak sekali bahwa hanya ada satu sperma saja yang membuahi sel telur dan sering disebut dengan fertilisasi. Ketika fertilisasi selesai maka dinding sel telur akan mengalami perubahan untuk mencegah penetrasi oleh sperma lain yang mendekati sel telur. Saat penetrasi, proses genetik telah berlangsung sempurna tumbuh dan membelah menjadi sangat cepat di dalam tuba fallopi dan 3-4 hari akan masuk ke dalam uterus pasca fertilisasi. Hal ini sesuai dengan pernyataan 6, pernyataan 7 , dan pernyataan 8 yang dibuat oleh peneliti. Dari pernyataan tersebut terlihat rata-rata jawaban mahasiswa tadris IPA pada pernyataan ke 6, yaitu 28 mahasiswa menyatakan sangat setuju dengan rata-rata 4,93 dan 2 mahasiswa menyatakan setuju, sedangkan pada pernyataan 7 yaitu pertemuan sel sperma dan sel telur terjadi di tuba fallopi dikategorikan sangat setuju dengan rata-rata 4,67 dari 20 mahasiswa yang menjawab sangat setuju dan 10 mahasiswa yang menjawab setuju.

Pada pernyataan ke-8 tentang morula meninggalkan tuba fallopi dan masuk ke dalam uterus 3-4 hari pasca fertilisasi terlihat 19 mahasiswa menyatakan sangat setuju dan 11 mahasiswa menyatakan setuju, jika dikategorikan maka pada pernyataan ke-8 ini mahasiswa dapat dinyatakan kategori sangat setuju dengan rata-rata 4,63. Jadi, dapat disimpulkan bahwa mahasiwa tadris IPA tidak ada yang miskonsepsi mengenai pernyataan bahwa sperma tersebut benar-benar berasal dari saripati tanah, terbentuknya janin akibat pertemuan sel sperma dan sel telur yang terjadi di tuba fallopi kemudian morulla akan meninggalkan tuba fallopi dan masuk ke dalam uterus (rahim) 3-4 hari pasca fertilisasi.

Selanjutnya pada pernyataan ke-9 diperoleh rata-rata 4,20 kategori sangat setuju dengan jawaban 14 mahasiswa menyatakan sangat setuju, 13 menyatakan setuju, 1 mahasiswa menyatakan tidak setuju dan 2 mahasiswa menyatakan sangat tidak setuju terhadap penyataan ke-9. Jadi, pada pernyataan 9 tentang perkembangan janin pada minggu ke-4 terjadi pembentukan jantung dan pembuluh darah, masih terdapat mahasiswa yang mengalami miskonsepsi meskipun hanya dalam kategori sedikit, yaitu hanya 3 mahasiswa saja dari 30 responden, sedangkan untuk pernyataan 10 dengan rata-rata 4,17 terdapat 15 mahasiswa yang menyatakan setuju, 12 mahasiswa 
yang menyatakan sangat setuju, 2 mahasiswa menyatakan tidak setuju dan 1 mahasiswa menyatakan tidak setuju terhadap pernyataan pada minggu ke-8 telah terjadi pembentukan kelopak mata dan telinga dan terkadang mulai terlihat pangkal hidung. Dari pernyataan tersebut masih ada mahasiswa yang miskonsepsi mengenai perkembangan janin pada tahapan minggunya. Sama seperti pernyataan 11 yaitu pada minggu ke-12 dengan alat khusus sudah dapat didengar detak jantung janin, di pernyataan ini dikategorikan sangat setuju karena 16 mahasiswa menyatakan sangat setuju, 11 menyatakan setuju, 1 mahasiswa menyatakan tidak setuju dan 1 mahasiswa menyatakan sangat tidak setuju sehingga hanya 2 orang mahasiswa saja yang miskonsepsi mengenai perkembangan janin di minggu ke-12.

Pada pernyataan 12 dikategorikan setuju dengan rata-rata 4,03. Mahasiswa menjawab setuju sebanyak 18 mahasiswa, sedangkan sangat setuju 9 mahasiswa, tidak setuju 1 mahasiswa dan yang sangat tidak setuju 2 mahasiswa, sehingga di materi perkembangan janin di usia 16 minggu, masih terdapat mahasiswa yang miskonsepsi sebanyak 3 mahasiswa. Jika dilihat pada teori perkembangan janin di minggu ke-16 tidak hanya pembentukan jantung dan pembuluh darah sudah sempurna tetapi jarijari tangan sudah memiliki sidik jari serta panjang bayi biasanya $11-12 \mathrm{~cm}$.

Pemeriksaan kehamilan dalam sains dapat dilakukan dengan USG, yaitu suatu alat untuk memeriksa dan meneliti keadaan janin yang di dalam rahim serta kondisi janin tersebut. USG (ultrasonografi) memanfaatkan gelombang suara yang dipancarkan ke dalam rahim yang akan memantulkan media yang diterima serta memproses yang hasilnya dapat ditayangkan dalam layar monitor bentuk asli di dalam rahim. Saat ini, USG merupakan salah satu metode dalam memberikan informasi yang akurat terkait keadaan janin/bayi dalam rahim. Hal ini terbukti ketika hasil yang di dapat membantu memperlihatkan langsung yang ada dalam rahim dan kondisi yang sama sesuai perkembangan janin tersebut. Seperti hasil dari rekaman kamera, namun hasilnya terlihat seperti kontur 3 dimensi. Pernyataan ini juga diperkuat dengan penelitian Suryani (2016) tentang pengaruh pelatihan ultrasonografi terhadap tingkat pengetahuan residen obstetri dan ginekologi mengenai keamanan penggunaan ultrasonografi obstetric, yaitu USG merupakan salah satu metode pencitraan yang aman bagi bayi, karena tidak menggunakan jarum suntik, obat-obatan maupun paparan radiasi. USG memanfaatkan pancaran serta pantulan gelombang suara dari rahim untuk menciptakan gambaran akan anatomi kandungan serta rahim.

Dari pernyataan 13 mengenai pemeriksaan USG umumnya dilakukan pada minggu ke-20, dikategorikan jawaban mahasiswa mengenai pernyataan ini adalah sangat setuju dengan rata-rata 4,77 yaitu dari 30 responden 23 mahasiswa menyatakan sangat setuju dan 7 mahasiwa menyatakan setuju, sehingga dalam konsep USG mahasiwa tadris IPA tidak ada yang mengalami miskonsep.

Selanjutnya, pada pernyataan ke-14 mengenai pernyataan yang berkaitan dengan Islam, yakni peniupan ruh yang terjadi setelah 120 hari atau 3 bulan yang sesuai dengan hadits Rasulullah "fase seorang manusia mulai diciptakan dalam perut ibunya diproses selama 40 hari, kemudian menjadi segumpal daging pada 40 hari 
berikutnya dan Allah mengutus malaikat untuk menghembuskan ruh dan menuliskan 4 hal, yaitu rezekinya, ajalnya, amalnya, dan sengsara atau bahagianya." Dari hadits tersebut dapat diambil garis lurus bahwa ruh ditiupkan ke dalam janin melalui 3 fase, yaitu nutfah, 'alaqah, dan mudhghah yang setiap fase berlangsung 40 hari lamanya sehingga jika di jumlahkah, yaitu selama 120 hari ruh tersebut ditiupkan dalam janin. Jika dianalisis dari tanggapan mahasiswa maka kategori tanggapan mahasiswa tentang pernyataan ini adalah sangat setuju dengan rata-rata 4,77. Mahasiswa tadris IPA tidak ada yang mengalami miskonsepsi mengenai jangka waktu peniupan ruh ini terlihat dari 26 mahasiswa yang menyatakan sangat setuju dan 4 mahasiswa yang menyatakan setuju.

Pada pernyataan 15 dikategorikan tanggapan responden sangat setuju karena pernyataan ini merupakan pernyataan yang sangat umum didengar, yang berkaitan dengan proses penciptaan manusia. Di surah Al-Mu'minum ayat 12-14 juga merupakan salah satu surah yang menjelaskan tentang proses penciptaan manusia, di pernyataan ke 15 ini tidak ada mahasiswa tadris IPA yang mengalami miskonsepi dengan rata-rata 4,97, dimana dari 30 responden, 29 mahasiswa menjawab sangat setuju dan 1 mahasiswa menjawab setuju.

Selain pernyataan yang positif didalam angket juga terdapat pernyataan yang negatif dengan hasil tabel seperti berikut.

Tabel 2. Hasil Analisis Pernyataan yang Negatif (Sesuai dengan Sains dan Islam)

\begin{tabular}{clccc} 
No. & \multicolumn{1}{c}{ Pernyataan } & Mean & Kategori \\
\hline 1 & $\begin{array}{l}\text { Pernyataan 3 (terdapat kesamaan antara embrio } \\
\text { manusia dan hewan) }\end{array}$ & 4,89 & Sangat Tidak Setuju \\
\hline 2 & $\begin{array}{l}\text { Pernyataan 4 (teori evolusi sesuai dengan } \\
\text { penciptaan manusia dalam sains) }\end{array}$ & 4,97 & Sangat tidak Setuju \\
\hline 3 & $\begin{array}{l}\text { Pernyataan 5 (teori evolusi sesuai dengan } \\
\text { penciptaan manusia dalam Islam) }\end{array}$ & 4,89 & Sangat tidak Setuju \\
\hline
\end{tabular}

Dari tabel pernyataan yang dibuat negatif pada pernyataan 3, yaitu terdapat kesamaan antara embrio manusia dengan embrio hewan, terdapat 27 mahasiswa menyatakan sangat tidak setuju dan 3 mahasiwa menyatakan tidak setuju dengan kategori sangat tidak setuju. Hal ini sesuai dengan teori bahwa embrio manusia berbeda dengan embrio hewan. Hal ini dipertegas oleh G. Rager seorang penulis buku Human Embriology and The Law of Biogenesis yang menyatakan bahwa heackel telah merekayasa gambar dengan cara menggunakan gambar yang sama dengan keterangan yang berbeda dengan memodifikasi gambar agar sesuai dengan aslinya (Latjnah, 2010).

Selanjutnya, pada pernyataan negatif yang terdapat dalam pernyataan 4 dan 5 tentang kesesuaian teori evolusi manusia dengan Islam dan sains, diperoleh rata-rata mahasiswa menjawab sangat tidak setuju. Hal ini terlihat pada pernyataan 4 tentang kesesuaian teori evolusi dengan sains dengan rata-rata 4,97 (sangat tidak setuju), terdapat 29 mahasiswa menjawab sangat tidak setuju dan 3 mahasiswa menjawab tidak setuju, sedangkan pada pernyataan 5 tentang kesesuaian teori evolusi dalam Islam 
dikategorikan mahasiswa tadris IPA sangat tidak setuju dengan rata-rata 4,89, yaitu 27 mahasiwa menyatakan sangat tidak setuju dan 3 mahasiswa menyatakan tidak setuju. Dari beberapa pernyataan negatif tersebut tidak ada mahasiswa yang miskonsepsi terhadap materi perkembangan janin baik dalam perspektif Islam maupun dalam perspektif sains.

\section{SIMPULAN}

Pemahaman konsep perkembangan janin dalam perspektif Islam dan sains yang telah dibagikan menunujukan bahwa pemahaman konsep Islam dan sains mahasiswa tadris IPA termasuk dalam kategori tinggi. Mahasiswa tadris IPA juga sudah dapat mengintegrasikan antara konsep Islam dengan sains. Oleh karena itu, sebagai mahasiswa tadris IPA yang merupakan calon guru IPA dari ilmu tarbiyah dan keguruan harus dapat mengintegrasikan antara Islam dan sains dalam pembelajaran yang diberikan kepada peserta didik. Terlebih lagi tantangan di era globalisasi saat ini mahasiswa tadris IPA memiliki kontribusi yang sangat besar untuk memberikan konsep IPA yang dapat menumbuhkan rasa tauhid dalam diri peserta didik. Hal ini dapat terealisasikan ketika mahasiswa tadris IPA memiliki pemahaman konsep yang benar mengenai IPA dalam perspektif Islam dan sains khususnya pada perkembangan janin manusia.

\section{DAFTAR PUSTAKA}

Abu al-Farj, A. al-R. I. A. I. R. al-H. (2003). Jami' al-'Ulum wa Al-Hukm (Jilid II). Beirut: Dar Al-Ma' rifah.

Abu al-Husain Muslim, bin al-H. bin M. al-Q. al-N. (2003). Sahih Muslim (Juz 1). Beirut: Dar Al-Afaq Al-Jadidah.

Al-Qurtubi, A. A. S. al-din. (2003). al-Jami' li Ahkam al-Qur'an (X). Riyadh: Dar 'Alim alKutub.

Al-Razi, F. A.-D. (2000). Mafatih Al-Gaib (XI). Beirut: Dar Al-Kutub Al-'Ilmiyah.

Arikunto. (2004). Prosedur Penelitian suatu Pendekatan Praktek. Jakarta: Rineka Cipta.

Hanifah, W. (2005). Ilmu Kebidanan (Ke-3). Jakarta: Yayasan Bina Pustaka Sarwono Prawirohardjo.

Hathout, H., \& Samer. (2002). Jihad Versus Terrorism Pasadena. California: Multimedia Vera International.

Ichromi, R. N. (2016). Konsep Pendidikan Pranatal dalam Pandangan dr. Mansur dan Ubes Nur Islam. UIN Maulana Malik Ibrahim Malang.

Latjnah, P. M. A.-Q. (2010). Tafsir Ilmu (Penciptaan Manusia dalam Perspektif Islam dan Sains). Kementrian Agama RI.

Ma'ruf, M. (2017). Konsep Pendidikan Pranatal Perspektif Islam. Al-Makrifat, 2(2), 124137.

Surana, D. (2001). Telaah Edukatif terhadap Fase-fase Perkembangan Manusia Perspektif Islam. Jurnal Ta'dib, 1(1), 47-59. 
Suryani, P. (2016). Pengaruh Pelatihan Ultrasonografi terhadap Tingkat Pengetahuan Residen Obstetri dan Ginekologi Mengenai Keamanaan Penggunaan Ultrasonografi Obstetri. Universitas Gadjah Mada.

Suwito. (2012). Penciptaan dan Pembentukan Janin Menurut Al- qur'an, Al -Hadis, dan Ilmu Kedokteran. Jurnal Hukum Islam Keluarga, 2(2).

Syauman, A. (2004). Ijhad Al- Haml Wama Yatarattabu'alaih min Ahkam fi Al-Syari'ah AlIslamiyyah. Jakarta: Cendekia Sentra Muslim.

Yuliati, D. (2000). Manajemen Komplikasi Kehamilan. Jakarta: Buku Kedokteran EGC. 